Ann. Biol. anim. Bioch. Biophys., I972, 12 (4), 679-683.

NOTE

\title{
ÉVOLUTION POSTPRANDIALE DE LA COMPOSITION GLUCIDIQUE DES CORPS MICROBIENS DU RUMEN EN FONCTION DE LA NATURE DES GLUCIDES DU RÉGIME
}

\author{
II. - LES BACTÉRIES \\ J.-P. JOUANY et P. THIVEND \\ Station de Recherches sur l'Élevage des Ruminants, \\ Centre de Recherches de Clermont-Ferrand, I. N.R. A., \\ Theix, 63110 Beaumont
}

Dans l'étude précédente (Jouany et Thivend, 1972), nous avons déterminé la composition glucidique des protozoaires extraits du rumen de bovins adultes recevant une ration dont le principal glucide était la cellulose, le saccharose, l'inuline ou l'amidon. Parallèlement, nous avons is šlé les bactéries libres du contenu de rumen et nous rapportons ici les résultats relatifs à leur composition glucidique.

Les bactéries obtenues après centrifugation fractionnée du contenu de rumen (JouANY et Thrvend, I972) ont été lyophilisées puis hydrolysées par $\mathrm{H}_{2} \mathrm{SO}_{4} \mathrm{~N}$ à I00 ${ }^{\circ} \mathrm{C}$ pendant 4 heures. L'hydrolysat a été ensuite neutralisé par $\mathrm{Ba}(\mathrm{OH})_{2} \quad 0,3 \mathrm{~N}$. Après avoir éliminé le précipité de $\mathrm{BaSO}_{4}$ par centrifugation, nous avons dosé les sucres présents dans le lyophilisat du surnageant par chromatographie en phase gazeuse (JouANY, 1972).

\section{RÉSUITATS}

Le glucose est le principal sucre libéré par l'hydrolyse acide (tabl. I), il représente de 2 à $20 \mathrm{p}$. roo de la matière sèche des bactéries. On trouve de faibles quantités de rhamnose, de ribose et de mannose dont les teneurs sont généralement inférieures à I p. Ioo ainsi que des traces de sucres aminés (glucosamine, galactosamine et $n$-acétyl galactosamine). L'ensemble de ces sucres représente, selon la nature du glucide du régime, de 3 à 25 p. Ioo de la matière sèche des bactéries.

La teneur en glucose de l'hydrolysat est très faible avec le régime "cellulose " (de $\mathrm{r}, 6$ à 2,7 p. 100 de la matière sèche) et reste peu importante ( 4 à 8 p. IOO) avec le régime " amidon ". 


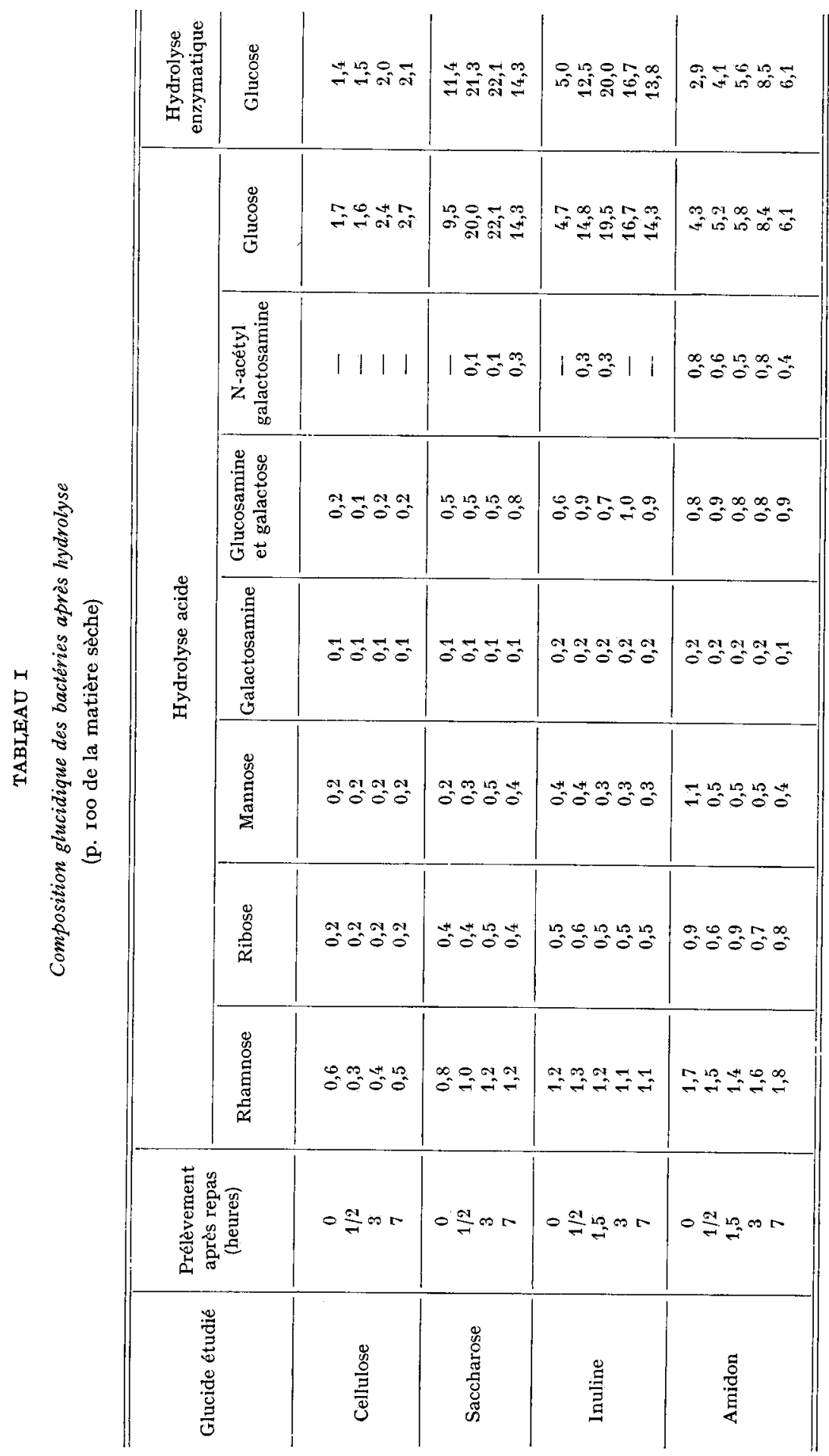


En revanche, elle peut atteindre de 20 à 22 p. Ioo avec les régimes " inuline " et " saccharose ". Les valeurs maximales sont d'autant plus importantes que le glucide ingéré par l'animal est facilement hydrolysable (fig .I). Ainsi, deux à trois heures après le début du repas, le glucose représente respectivement $22, \mathrm{I}$ et $\mathrm{I9,5}$ p. Ioo de la matière sèche pour les régimes " saccharose " et " inuline » et seulement 8,4 p. Ioo pour le régime " amidon ". Nous avons observé inversement (JouANy et THrvend, 1972) que la teneur en glucose des protozoaires est maximum avec les glucides cytoplasmiques dont la dégradation dans le rumen est progressive (amidon et inuline).

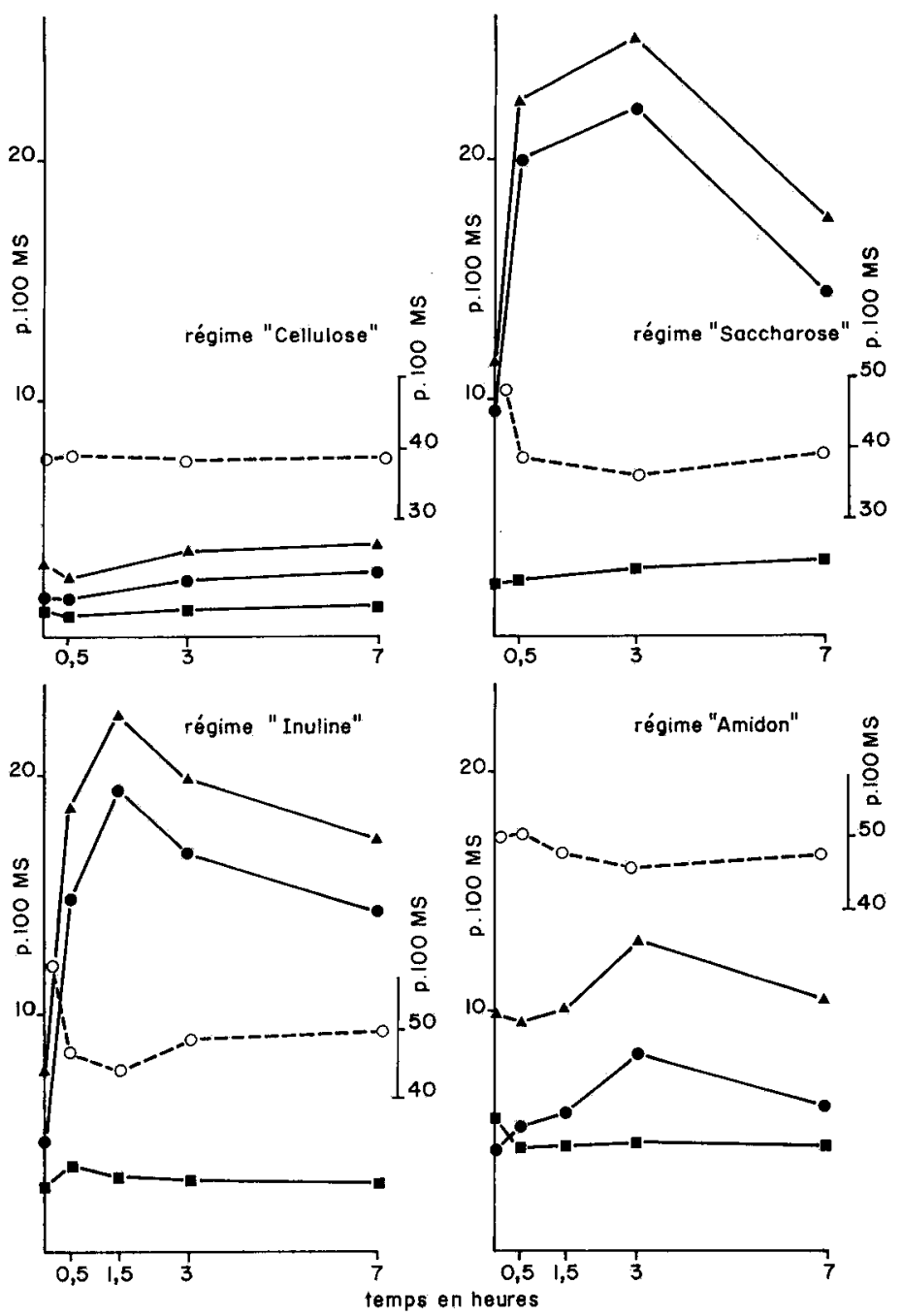

FIG. I. - Evolution postprandiale de la composition des bacteries

(après hydrolyse acide par $\mathrm{H}_{2} \mathrm{SO}_{4} \mathrm{~N}$ à $\mathrm{Ioo}^{\circ} \mathrm{C}$ )

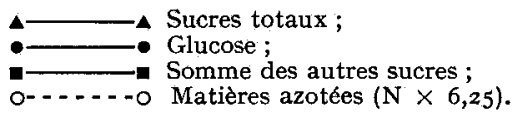


Le glucose n'existe pas à l'état libre dans les bactéries du rumen. Nous avons montré, en effectuant une hydrolyse enzymatique par la glucamylase (Thivend, Mercier et GuILBot, 1965), qu'il provenait, en quasi-totalité, d'un polyholoside de réserve dont la structure est très voisine de celle de l'amidon ou du glycogène (tabl. I). Ces résultats sont en accord avec ceux de Heald (1951), d'Hobson et Mann (1955), de Doetsch et al. (1957), de Bailey et Oxford (1958) et d'Hungate (1963), qui indiquent la formation rapide d'un polymère du glucose,lorsque les bactéries disposent de sucres solubles.

La concentration des autres sucres de l'hydrolysat est très faible. Ils représentent de I à $5,5 \mathrm{p}$. Ioo de la matière sèche des bactéries. Cette proportion est plus importante avec les régimes "inuline " (3 p. IOo) et "amidon " (4 à 5 p. roo) qu'avec les régimes "saccharose " et "cellulose ". $\mathrm{La}$ concentration de ces différents sucres reste constante après le repas, pour un régime donné. Selon BAILEY et OXFord (1958) et Costerton (I970), le galactose, le rhamnose, les sucres aminés ainsi qu'une faible proportion de glucose, pourraient provenir, soit des mucopolysaccharides soit des lipopolysaccharides des capsules de bactéries. Le ribose provient vraisemblablement de l'hydrolyse des acides nucléiques, tandis que le mannose mis en évidence également par HooGENRAAD et HiRD (1970) serait un glucide qui entre dans la composition des parois de certaines bactéries (Bull, 1970). Contrairement à Niven, Smiley et Sherman (I94I), nous n'avons jamais observé de fructose dans l'hydrolysat des polyholosides de réserve des bactéries, même avec les rágimes riches en saccharose ou en inuline.

En conclusion, la teneur en polyholosides de réserve des bactéries est très variable. Avec les régimes à base de cellulose et d'amidon, elle est faible ( 4 à 8 p. roo) et n'évolue que très lentement après le repas. En revanche, elle peut constituer jusqu'à 20 p. roo de la matière sèche des bactéries avec les régimes riches en glucides facilement fermentescibles (inuline, saccharose). Les polyholosides de réserve des bactéries sont essentiellement des polymères du glucose que l'on peut doser facilement en effectuant une hydrolyse acide suivie d'un dosage spécifique du glucose obtenu.

Reçu pour publication en mars 1972.

\title{
SUMMARY
}

\author{
THE CHANGES IN THE CARBOHYDRATE OF THE RUMEN'S MICROBIAL, \\ POPULATION FOLLOWING FEEDING IN RELATION TO THE DIETARY \\ CONTENT OF CARBOHYDRATES. II. — BACTERIA
}

The amount of carbohydrate present in bacteria and hydrolyzable by $\mathrm{H}_{2} \mathrm{SO}_{4} \mathrm{~N}$ at $100^{\circ} \mathrm{C}$ for 4 hours varies according to the nature of the dietary carbohydrate : 3.9, 13.0, 22.7, and $25.0 \mathrm{p}$. Ioo of the dry matter, respectively, for diets rich in cellulose, starch, inuline, and saccharose. This quantity rapidly increases after the beginning of the meal in "saccharose " and "inuline" diets, and much more slowly when "starch" and " cellulose " diets are given. Only glucose, the main carbohydrate liberated by acid hydrolysis, changes in quantity to reach a maximum $2-3$ hours after the beginning of the meal.

Smaller amounts of thamnose, ribose, mannose, and amino sugars are also found in the microbial population (less than or equal to 1 p. Ioo). 


\section{RÉFÉRENCES BIBLIOGRAPHIQUES}

BAILEY R. W., OXFord A. E., I958. A quantitative study of the production of dextran from sucrose by rumen strains of Streptococcus bovis. J. Gen. Microbiol., 19, $130-145$.

Butl A. T., 1970. Chemical composition of wild-type and mutant Aspergillus nidulans cell walls. The nature of polysaccharide and melanin constituents. J. Gen. Microbiol., 68, 75-94.

Costerton J. W., I97o. The structure and function of the cell envelope of gram-negative bacteria. Rev. Can. Biol., 29, 299-316.

Doetsch R. N. Howard B. H., Mann S. O., Oxpord A. E., 1957. Physiological factors in the production of an iodophilic polysaccharide from pentose by a sheep rumen bacterium. J. Gen. Microbiol., 16, I56-I68.

HEAld P. J., I95 I. The estimation of glucose-containing substances in microorganisms from the rumen of the sheep. Br. J. Nutr., 5, 75-83.

Hobson P. N., MANN S. O., I955. Some factors affecting the formation of iodophilic polysaccharide in group D Streptococci from the rumen. J. Gen. Microbiol., 13, 420-435.

HoogenraAd N. J., Hird F. J. R., I970. The chemical composition of rumen bacteria and cell walls from rumen bacteria. Br. J. Nutr., 24, II9-127.

Hungate R. E., I963. Polysaccharide storage and growth efficiency in Ruminococcus albus. $J$. Bacterial., 86, 848-854.

Jouany J. P., 1972. Chromatographie en phase gazeuse des oses, des di- et triholosides dans les milieux complexes. Ann. Biol. anim. Bioch. Biophys. 12, 493-504.

Jouany J. P., Thrvend P., I972. Évolution postprandiale de la composition glucidique des corps microbiens du rumen en fonction de la nature des glucides du régime : I. les protozoaires. $A n n$. Biol. anim. Bioch. Biophys. 12, 673-677.

Niven C. F., Smiley K. L., Sherman J. M., r94I. The polysaccharides synthesized by Streptococcus salivarius and Streptococcus bovis. J. Biol. Chem., 140, ro5-109.

Thivend P., Mercier C., Guilbot A., r965. Dosage de l'amidon dans les milieux complexes. Ann. Biol. anim. Bioch. Biophys., 5, 513-526. 